International Journal of Language Education

Volume 5, Number 4, 2021, pp. 324-336

ISSN: $2548-8457$ (Print) 2548-8465 (Online)

Doi: https://doi.org/10.26858/ijole.v5i4.19732

\title{
Investigating the Problems of Learning Arabic for Islamic Universities in the Era of Covid-19 Pandemic
}

\author{
Rahmawati \\ UIN Imam Bonjol Padang, Indonesia \\ Email:rahmawati@uinib.ac.id \\ Suci Ramadhanti Febriani \\ UIN Imam Bonjol Padang, Indonesia \\ Email: suciramadhantifebriani11@gmail.com
}

Received: 19 March 2021

Reviewed: 1 August 2021-30 October 2021

Accepted:5 December 2021

\begin{abstract}
The 2019 Coronavirus pandemic (COVID-19) creates challenges for the Arabic learning process at Indonesian Islamic Universities, which is one of the mandatory subjects to support foreign language communication. This research aims to analyze the problems of learning Arabic at UIN Imam Bonjol Padang in the situation of COVID-19 pandemic. This research utilise case studies based on data includes observations of Arabic learning processes, collecting documentation through lesson plans and interviews with Arabic lecturers. The data analysis technique employs data triangulation through data collection, data reduction, data presentation, conclussion. The results ascertain that Arabic learning activities showed less effectiveness in COVID-19 situation, this was due to the varied problems of learning Arabic based on online learning; the teacher's experience in designing online-based interactive media, the minimum stable learning platform, the minimal control process on students' language acquisition and supporting facilities in learning Arabic online. The findings of this study discover that Arabic lecturers to integrate all learning components holistically, so the Arabic learning process can achieve maximum outcomes. This research recommends to the other research to find a solution to every problem that exists in Arabic learning in COVID-19 situation at UIN Imam Bonjol Padang.
\end{abstract}

Keywords: Arabic learning; COVID-19; media; online learning; problematics

\section{Introduction}

Currently, the world is shocked by the case of a deadly virus known as Coronavirus-19 or COVID-19, which is endemic in Indonesia (Pininta, 2020). Related to a virus that has become a pandemic in the world, which has a profound impact on the education system in Indonesia, this virus has also caused significant changes in the learning system in Indonesia, as well as the foreign language learning process (Dhawan, 2020). The learning process for foreign languages, especially Arabic, is usually held in classrooms, with a structured system, prepared materials (Febriani, et al., 2020), and several factors that support the success of learning such as adequate facilities and infrastructure to change direction in the online learning process. 
This aims to give student experiences more varied even though they follow the online learning (Richardson et al., 2016), because there is actually a positive relationship between using of technology and language to expand the reach in expressing language (Chun et al., 2016; Jalaluddin, 2016). Learning Arabic in the situation of COVID-19 is facing challenges. The limitations experienced by students have a broad impact on learning output (Mietzner et al., 2020). As it is known that limitations can be in the form of internal factors and external factors.

The learning process adopted face-to-face has turned into online learning during the COVID-19 pandemic. Various competencies are mendatory to overcome this aspect. As one of them is the ability of the teacher to manage the class well. Learning activities during the COVID19 pandemic experienced rapid changes. Activities that refer to students encourage various groups to innovate in the use of learning media (Zaharah \& Kirilova, 2020). However, there are still many problems faced by teachers in Islamic Universities. On that basis, it requires for fundamental studies related to the problems of learning Arabic in COVID-19 situation at UIN Imam Bonjol Padang.

Efforts to improve the Arabic learning process at UIN Imam Bonjol Padang are adopting learning using an online media platform. For this statement, the researchers aim to analyze how the lecturers respond and examine the problems faced with the acquisition of Arabic during onlinebased learning. The psychological condition of students (Wahab, 2016), the learning environment (Hatamleh \& Almuslamani, 2020; Mahmudi et al., 2019), and their perceptions can determine the achievement of learning goals (Bahruddin \& Febriani, 2020), and using of learning strategies also encourages the successful achievement of learning goals (Barnabas et al., 2019).

In essence, the online media-based Arabic learning process in the era of the COVID-19 emergency offers flexibility and convenience for students. The online learning process is also less effective if the minimum number of teachers in providing instructions to students regarding the material to be discussed (Dočekal \& Tulinská, 2015). Lack of face-to-face online classes can create psychological distance and feelings of isolation and disconnection, even for students who are not accustomed to using online learning, it will cause its own barriers (Olmanson \& Liu, 2018).

However, several studies have shown that the role of an instructor is the main element in encouraging students to take an active role in online language learning (Hart, 2012). Researchers agree that the interaction between teachers and students is the main concept in facilitating quality online learning. In relation to online-based foreign language learning, several previous studies have shown that the foreign language learning process using online media has a positive impact on student interaction (Bowers \& Kumar, 2015), increases collaborative relationships between students (Peeters, 2018), increases linguistic participation, equal opportunity to learn languages (Moeller \& Abbott, 2018), and improve student achievement in foreign languages (Mellati \& Khademi, 2015). There is still a need for a basic study regarding the investigation of problematics in learning Arabic in the era of COVID-19 at UIN Imam Bonjol Padang as an effort to improve the quality of language learning at the tertiary level.

\section{Literature review}

Online system-based learning has been widely implemented. This is related to the efficiency and effectiveness of the learner's space and time. As it is known, one of the important points in online-based learning is the use of online media that suits the needs of learners. One of the effective media that can be required to develop authentic language experiences is through media zoom (Lenkaitis, 2019). Online learning requires a variety of supporting facilities in order 
to achieve the success of learning objectives. When the facilities do not meet the standards, online learning is not effective (Fauzi \& Khusuma, 2020).

Online learning during the COVID-19 pandemic is inefficient because it costs more than face-to-face systems (Bahasoan et al., 2020). Another supporting factor is the competence of teachers in managing the learning system. Teachers must ensure learning goes well as the responsibility and professionalism of a teacher (Safutri et al., 2020). Teachers mendatory to determine the appropriate media in learning Arabic. As one of the instruments is using of videoconference which is a very effective learning tool. This is due to the use of communication that allows users to connect and share visual and audio facilities in real time (Al-samarraie, 2019). In the face of the conditions of COVID-19, the government has issued a ban for universities to carry out face-to-face lectures and ordered online learning through the Ministry of Education and Culture of Higher Education Circular No.1 of 2020. Universities are required to organize online learning with learning scenarios that prevent physical contact between lecturers and students and between students and students (Firman \& Rahayu, 2020). Online learning is an alternative form of learning that can be done to reduce the spread of COVID-19.

Online learning uses internet networks with accessibility, connectivity, flexibility and the ability to generate various types of learning interactions (Balasopoulou et al., 2017). In its implementation, online learning requires supporting mobile devices such as smartphones, laptops, computers, tablets and iPhones which can be used to access information anytime and anywhere (Gikas \& Grant, 2013). To support online learning, various media can be used such as virtual classes using Google Classroom, Slack, Asana, Email, Line, Skype, Youtube or Zoom, Edmodo (Enriquez, 2020; Iftakhar, 2016; Sicat, 2020),or by using instant messaging applications such as WhatsApp (Li, 2017; So, 2016), and it can even be done through social media such as Facebook and Instagram (Kumar \& Nanda, 2018).

According to Pangondian (2019), there are several factors that influence the success of online learning; technology, teacher character and student character. Technology, is related to the availability of media and networks that allow online communication and interaction between teachers and students. The teaching character, in online learning requires teachers / lecturers to have a positive, adaptive attitude and master technology. Likewise, from the student aspect, it requires students who are disciplined, intelligent and have high self-confidence.

\section{Research method}

Subjects

This study used a case study method for investigating the problematics of Arabic learning in COVID-19 situation at UIN Imam Bonjol Padang. As a case study research aims to discover the phenomenon of the object of study holistically and deeply (Yin, 2003). This study aims to reveal the phenomenon of the problems faced in learning Arabic in the Arabic Language Education. Researchers apply 10 Arabic lecturers for giving informations under the auspices of the Tarbiyah and Teaching Faculty of UIN Imam Bonjol Padang.

\section{Data collection techniques}

Data collection techniques include interviews, observation and documentation. Researchers distributed questionnaires in the form of detailed questions related to problems faced by lecturers in learning Arabic online. Then, researchers used observation techniques to explore the process of learning Arabic online. Observation activities were carried out randomly in Arabic online learning classes to obtain detailed data and conformity with the data from documentation 
and the results from of interviews with Arabic language lecturers. After that, researchers used documentation such as lesson plan in online learning that was implemented in the classroom. Documentation also aims to obtain the facts about online Arabic learning to explore problems faced by lecturers in learning Arabic during the COVID-19 pandemic.

Procedure and data analysis

The data analysis technique uses the triangulation technique with the steps as follows.

- Data collection. The researchers collected data from the observation, as the researchers notes the existing activities related to problematics in Arabic learning based on online system in UIN Imam Bonjol Padang. As for the information from the documents, the researchers collect it through lesson plan about problematics in Arabic learning.

- Data classification. In the data classification, the researchers reduced the data related to the case and classified it as encoding. In classifying data, the researchers focused on data related to the problematics in Arabic learning based on online system in the era of COVID-19 pandemic.

- Display data. The step in which the data is reduced is the data display. Data presentation is the process of presenting and processing it, which includes: the process of identification, classification and organization, and explanation methodically, objectively, and comprehensively, and finally comes the interpretation.

- Conclusion. The last step is to take deduction. In this step, the researchers concluded the research findings according to the researcher's classifications and according to the interpretations.

\section{Findings and discussion}

The Arabic learning process at UIN Imam Bonjol Padang uses an online-based learning system in the Covid-19 situation. This is a campus policy effort to suppress the growth of the COVID-19 virus. Even though the learning process is online based, the learning strategies used are still student-oriented. This is evidenced by the instruction used by the teacher is not more dominant than the efforts made by students to develop the potential for Arabic language.

However, some of the problematics faced by lecturers when learning Arabic during the pandemic. Its also important points in achieving student learning outcomes. As with the mapping of the problems faced by lectures when learning Arabic based online at UIN Imam Bonjol Padang, it can be described in the following table.

Table 1. The Classification of Problematics in Arabic Learning

\begin{tabular}{cll}
\hline Numb & Aspect & The Problematics \\
\hline 1 & Strategy & $\begin{array}{l}\text { The mixed learning process is an option in learning during the COVID-19 } \\
\text { pandemic } \\
\text { Media Lack of experience and mastery of technology for lecturers }\end{array}$ \\
2 & $\begin{array}{l}\text { Media } \\
\text { Teaching }\end{array}$ & $\begin{array}{l}\text { Designing platform-based teaching materials } \\
\text { Materials }\end{array}$ \\
4 & $\begin{array}{l}\text { Monitoring } \\
5\end{array}$ & $\begin{array}{l}\text { The minimal interaction between lecturers and students in learning } \\
\text { The lack of interaction between students and lecturers has an impact on }\end{array}$ \\
6 & $\begin{array}{l}\text { Enthusiasm } \\
\text { Lecturer }\end{array}$ & $\begin{array}{l}\text { The ludent enthusiasm for learning Arabic } \\
\text { The ability of lecturers to design integrated material on the online platform }\end{array}$ \\
& Competence & \begin{tabular}{l} 
is still minimal \\
\hline
\end{tabular}
\end{tabular}


Based on Table 1, it is known that the problems faced by Arabic lecturers at UIN Imam Bonjol Padang are very complex. As efforts that are improved in online-based learning are the ability of teachers in online classroom management, structuring skills-based language learning evaluations. The online Arabic learning process is directed at skill-based learning media (Alghamdi, 2018; Ritonga et al., 2020; Wargadinata et al., 2020). This is supported by previous research that scaffolding for teachers needs to be increased along with the demands and needs of the times (Abdurrahman et al., 2019; Lee, 2017).

To support the learning process, various learning media platforms have been used.

As Aruan et al., (2020) said that using of variate media can reduce the saturation of student learning. This aims to provide a variety of strategies in learning even though it is online based. Learning presentations through WhatsApp groups, zoom and google classrooms are the tendency for lecturers to choose media as a learning resources.

In online learning, the lecturer gives instructions to students for following the online lessons using the zoom link or google meet. After that, students can present their assignments and there is a question and answer session. However, one of the lecturer revealed that:

"The lack of student interaction and their responses during discussions also hampers and lacks learning outcomes. This is due to the limited internet network of students, as well as their lack of motivation in online learning" (Interviews 2nd).

Based on the statement, the lecturer continue to strive for a varied learning process using a variety of media. As the use of varied learning media can be seen through the following picture.
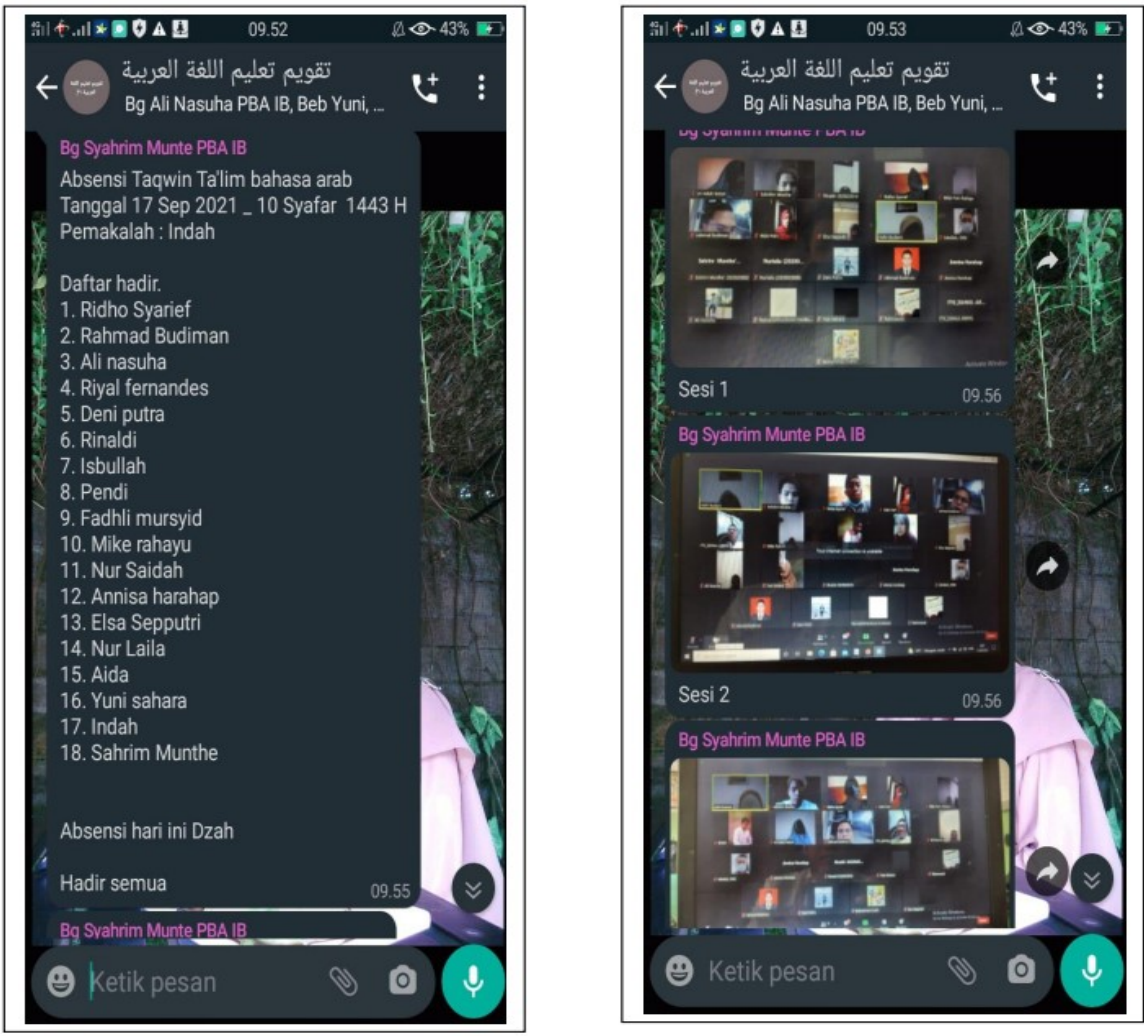

Figure 1. Media Application 
Based on Figure 1, the media is in the form of Power Point, Video, Recorder, and Audio. As the media is the most widely used learning resource and contributes greatly in facilitating the transmission of material (Soffer et al., 2017).

Through different media, it is hoped that students can maximize their potential from various online learning sources (Shomurodovich, 2020; Turan \& Akdag-Cimen, 2020). As it is described, using of media is adjusted to the teaching material that has been determined. Teachers can assess the effectiveness of each of these media according to the needs of students. This was similarly explained by one of the informants that:

"Learning Arabic using WhatsApp group and Google classroom media is employ to maximize student and lecturer interaction" (Interview 1st).

Based on this statement, learning activities during the COVID-19 pandemic also vary. For example, the minimized use of lecture strategies, the most dominant use of discussion strategies , assignments and exercises to improve students' Arabic language skills. The language learning strategy is directed towards increasing communication interactions based on improvisation, simulation, dialogue and conversation through debate (Rear, 2017; Setiawan, 2017; Suparsa et al., 2017). One of the informants also emphasized that the enthusiasm of students in participating in learning was still high with a variety of communication strategies. This was revealed by one of the informants that:

"Learning activities through various strategies form the enthusiasm of students. This is because these activities encourage them to dig up material information provided during the introduction to the learning process"(Interview 2nd).

Through this expression, the system used by lecturers in improving Arabic language skills at UIN Imam Bonjol Padang tends to use a process of assignments, discussions and exercises. This can be seen in the following figure.

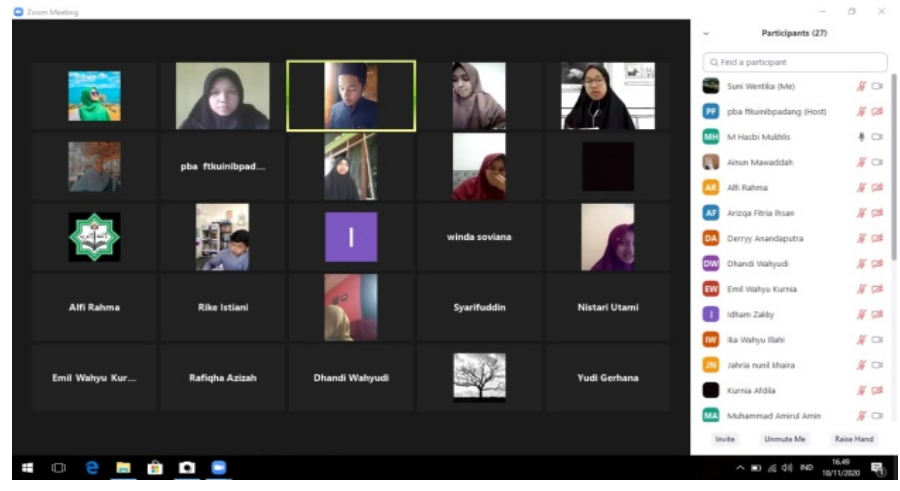

Figure 2. Learning Activities

Based on Figure 2, it is known that the online-based Arabic learning process has minimal face-to-face interaction, it is indicated that the student's response when the lecturer explains or provides material is very minimal. Even though online learning has an impact on lecturer, paying attention to strategies that suit their needs is a top priority. As stated, developing the ability to choose strategies is the most effective way to achieve learning goals (Barotovna \& Bafakulovna, 
2020). This can provide opportunities for each student to develop themselves in Arabic language competence. As Mohd et al., (2019) explained that the training process can provide opportunities for more intense interaction between teachers and students to discuss topics that have not been mastered.

Online-based Arabic learning in the era of the COVID-19 pandemic presents an urgent problematics for lecturers. As one informant showed that:

"The problematics faced by Arabic language lecturers are the lack of togetherness and activity in interaction with students, minimal signal conditions and students who do not join online learning make it difficult for lecturers to give assessments" (Interview 4th).

This is one of the points for education providers' policies to ensure facilities that can support the implementation of the learning process even in online learning during the COVID-19 pandemic. As described, facilities are a supporting factor for successful learning (Shattock, 2017).

Using of various media also requires lecturers to develop themselves in designing effective learning. As Rabiman et al., (2020) explain that traditional learning requires more energy to deliver teaching material, in contrast to online learning it can be positive that teaching materials can be accessed, stored and shared via the internet.

Online learning also makes it difficult for teachers to monitor and change student behavior in the short term. This is due to the focus of the teacher in designing online material (Aruan et al., 2020). As one of the lecture responses in online learning as follows:

"Software-based media makes it difficult for lecturers and spends a lot of time for preparing teaching materials" (Interview 4th).

Based on this statement, the effort that needs to be maximized is the improvement of pedagogical competence in teaching. This can be in the form of increasing seminars, conferences, training related to increasing the ability of teachers to design media online (Abdurrahman et al., 2019). So, the learning process that is applied can be more effective for teachers and students. As one informant stated that:

"Learning resources used by lecturers are through books, internet, journals, YouTube videos and dictionaries. (Interview 5th).

Through this statement, the lecturer can compile their own teaching materials, as well as maximize learning resources available on the internet and provide instructions for students to do independent assignments. This is part of increasing the ability of students through teaching instructions and independent and group assignments (Moeller \& Catalano, 2015).

Teachers also felt the various obstacles faced when using teaching materials such as the lack of student feedback, less than optimal time management and internet networks, heterogeneous student input, limited access to campus libraries and inadequate evaluation processes. Some of the obstacles faced by lecturers are important points in the effort to improve lecturer competence in teaching. As the competence of lecturers in teaching will determine the learning outcomes of students (Safutri et al., 2020). This is related to fluency and fluency in learning Arabic in the COVID-19 era, which is still classified as a less than optimal achievement.

As Wekke \& Hamid (2013) explained that the facility is a benchmark in accommodating the development of learning for students and teachers. One of the informants informed that: 
"The unavailability of a special building for Arabic Language Education student activities and the use of learning platforms that have not been maximized has an impact on learning outcomes that are not optimal. (Interview 6th).

Based on this description, it is hoped that policy makers can provide maximum facilities and provide a learning platform that is easier to use. In addition, holding online media training and providing more stable platform facilities can be an effort to minimize the less than optimal impact of learning (Dočekal \& Tulinská, 2015). The application of training to deliver online material is an important option for optimal learning (Fatani, 2020).

It can be seen that learning Arabic during the COVID-19 pandemic has not been optimal. Based on the fact that language acquisition still requires face to face so that it can make it easier for lecturers to provide input and suggestions for improving the language of students (Huang, 2016). In addition, assessment in the language process cannot be absolute through the platform alone, but there are still many things that have not been monitored in assessing students (Bahruddin \& Febriani, 2020).

It is known that the factors that influence learning Arabic are influenced by internal and external factors (Hasyim, 2015). During the COVID-19 condition, students can study independently by enriching material sources from the internet. Motivational support from parents and themselves also has a positive impact on the online learning process.

The abilities of the teachers are packed with four balanced competencies; pedagogical, social, personal and professional competencies. Through online-based learning, it is hoped that the improvement of each competency for teachers will continue to be developed, especially in mastery of educational technology (Averkieva \& Kachalov, 2020; Nazmieva et al., 2019; Soffer \& Nachmias, 2018). Pedagogical innovation also supports learning, professionalization and suppresses remote access for learners (Febriani, et al., 2020; Walder, 2017).

This aims to maximize the output of Arabic language learning even though online learning. However, actually online-based learning makes it easy for teachers, students to explore sources of teaching material information. As it is known, online learning satisfaction is seen from the aspect of well-designed material content (Alqurashi, 2019). So, the learning process is not only obtained in online classes, but project-based independent assignments can be an option for developing student competencies outside of online classes.

The implication of this research is to map the problems faced by lecturers in online-based Arabic learning. So, this research can be a reference for scientific development or solving problems faced through the necessary policies. This can encourage the improvement of optimal Arabic learning outcomes.

\section{Conclusion}

The investigation of problematics in learning Arabic during the COVID-19 pandemic showed that it was not optimal in achieving the objectives of learning Arabic at UIN Imam Bonjol Padang. It is marked by the lack of time allocation, network limitations, and the lack of internal student motivation and instructor instruction as well as the ability to manage learning for teachers in the online learning system. The process of learning Arabic online is influenced by various determinants, such as student internal motivation, teacher monitoring, adequate facilities and easily accessible material. This encourages the improvement of online-based Arabic learning at UIN Imam Bonjol Padang in the future. This study recommends other researchers to solve the obstacles faced in online learning, both in terms of media or other more varied aspects. This research reveals how teacher perceptions and problems when learning Arabic during COVID-19 
can have a positive impact in increasing teacher competence more intensely. This makes it possible to integrate teacher's competencies with other learning supporting factors, so the students can achieve maximum learning outcomes.

Declaration of conflicting interest

The authors declare that there is no conflict of interest in this work.

Funding acknowledgement

The author would like to thank the Dean of the Tarbiyah and Teaching Faculty for supporting the research and the DIPA of UIN Imam Bonjol Padang who has funded this publication.

\section{References}

Abdul Wahab, M. (2016). Standarisasi Kurikulum Pendidikan Bahasa Arab Di Perguruan Tinggi Keagamaan Islam Negeri. Arabiyat: Jurnal Pendidikan Bahasa Arab Dan Kebahasaaraban, 3(1), 32-51. https://doi.org/10.15408/a.v3i1.3187

Abdurrahman, A., Nurulsari, N., Maulina, H., Rahman, B., Umam, R., \& Jermsittiparsert, K. (2019). Multi-level scaffolding: A novel approach of Physics Teacher Development Program for promoting content knowledge mastery. International Journal of Innovation, Creativity and Change, 7(8), 71-89.

Al-samarraie. (2019). Al-samarraie-2019-A Scoping Review of Videoconferencing Systems in HE.pdf. International Review of Research in Open and Distributed Learning, 20(3), 122.

Alghamdi, M. A. (2018). Arabic Learners' Preferences for Instagram English Lessons. English Language Teaching, 11(8), 103. https://doi.org/10.5539/elt.v11n8p103

Alqurashi, E. (2019). Predicting student satisfaction and perceived learning within online learning environments. Distance Education, 40(1), 133-148. https://doi.org/10.1080/01587919.2018.1553562

Aruan, L., Sari, R., \& Bengar Harahap, A. (2020). Using Prezi Online Software to Improve Teaching Listening Skill. International Journal of Education and Literacy Studies, 8(1), 104. https://doi.org/10.7575/aiac.ijels.v.8n.1p.104

Averkieva, L., \& Kachalov, N. (2020). Internet technologies in foreign language learning. International Journal of Sciences and Humanities, 4(2), 50-56.

Bahasoan, A. N., Wulan Ayuandiani, Muhammad Mukhram, \& Aswar Rahmat. (2020). Effectiveness of Online Learning In Pandemic Covid-19. International Journal of Science, Technology \& Management, 1(2), 100-106. https://doi.org/10.46729/ijstm.v1i2.30

Bahruddin, U., \& Febriani, S. R. (2020). Student's perceptions of Arabic online learning during COVID-19 emergency. Journal for the Education of Gifted Young Scientists, 8(4), 14831492. https://doi.org/http://dx.doi.org/10.17478/jegys.760735

Balasopoulou, A., Kokkinos, P., Pagoulatos, D., Plotas, P., Makri, O. E., Georgakopoulos, C. D., Vantarakis, A., Li, Y., Liu, J. J., Qi, P., Rapoport, Y., Wayman, L. L., Chomsky, A. S., Joshi, R. S., Press, D., Rung, L., Ademola-popoola, D., Africa, S., Article, O., ... Loukovaara, S. (2017). Symposium Recent advances and challenges in the management of retinoblastoma Globe - saving Treatments. BMC Ophthalmology, 17(1), 1. https://doi.org/10.4103/ijo.IJO

Barnabas, R. A., Rafli, Z., \& Rasyid, Y. (2019). Cognitive and Metacognitive Strategies in Arabic Listening Learning and Relationship with Student's Personlaity.Arabiyât. 6(2), 254-271. 
Barotovna, D. G., \& Bafakulovna, N. N. (2020). Use of Innovative Methods in Foreign Language Teaching. International Journal of Progressive Sciences and Technologies (IJPSAT), 23(2), 402-404. http://ijpsat.ijsht-journals.org

Chun, D., Smith, B., \& Kern, R. (2016). Technology in Language Use, Language Teaching, and Language Learning. Modern Language Journal, 100, 64-80. https://doi.org/10.1111/modl.12302

Dhawan, S. (2020). Online Learning: A Panacea in the Time of COVID-19 Crisis. Journal of Educational Technology Systems, 49(1), 5-22. https://doi.org/10.1177/0047239520934018

Dočekal, V., \& Tulinská, H. (2015). The Impact of Technology on Education Theory. Procedia Social and Behavioral Sciences, 174, 3765-3771. https://doi.org/10.1016/j.sbspro.2015.01.1111

Enriquez, M. A. (2020). Students 'Perceptions on the Effectiveness of the Use of Edmodo as a Supplementary Tool for Learning. DLSU Research Congress. https://doi.org/https://doi.org/10.1017/CBO9781107415324.004

Fatani, T. H. (2020). Student satisfaction with videoconferencing teaching quality during the COVID-19 pandemic. BMC Medical Education, 20(1), 1-8. https://doi.org/10.1186/s12909020-02310-2

Fauzi, I., \& Sastra Khusuma, I. H. (2020). Teachers' Elementary School in Online Learning of COVID-19 Pandemic Conditions. Jurnal Iqra' : Kajian Ilmu Pendidikan, 5(1), 58-70. https://doi.org/10.25217/ji.v5i1.914

Febriani, S. R., Wargadinata, W., Syuhadak, S., \& Adam, F. M. (2020). Design of Arabic Learning for Senior High School in the 21 st Century. 12(1), 1-21. https://doi.org/10.24042/albayan.v12i1.5886

Febriani, S. R., Widayanti, R., Amrullah, M. A., \& Mufidah, N. (2020). Arabic Learning for Elementary School During COVID-19 Emergency in Indonesia. OKARA, 14(1), 67-80. https://doi.org/10.19105/ojbs.v14i1.3194

Firman, F., \& Rahayu, S. (2020). Pembelajaran Online di Tengah Pandemi Covid-19. Indonesian Journal of Educational Science (IJES), 2(2), 81-89.

Gikas, J., \& Grant, M. M. (2013). Mobile computing devices in higher education: Student perspectives on learning with cellphones, smartphones \& social media. Internet and Higher Education. https://doi.org/https://doi.org/10.1016/jjheduc.2013.06.002

Hasyim, M. (2015). Andragogi Dalam Pembelajaran Bahasa Arab. ARABIYAT: Jurnal Pendidikan Bahasa Arab Dan Kebahasaaraban, 2(1), 31-42. https://doi.org/10.15408/a.v2i1.1512

Hatamleh, I. M., \& Issa Almuslamani, H. A. (2020). Classroom Participation: Nursing Students Perspective Paper Critique. International Journal of Higher Education, 9(6), 236. https://doi.org/10.5430/ijhe.v9n6p236

Huang, Q. (2016). Learners' Perceptions of Blended Learning and the Roles and Interaction of f2f and Online Learning. ORTESOL Journal, 33(2013), 14-33.

Iftakhar. (2016). Google Classroom: What Works and How? Journal of Education and Social Sciences.

Jalaluddin, M. (2016). Using YouTube to Enhance Speaking Skills in ESL Classroom. English for Specific Purposes World.

Kumar, \& Nanda. (2018). Social Media in Higher Education. International Journal of Information and Communication Technology Education. https://doi.org/Kumar, V., \& Nanda, P. (2018). 
Social Media in Higher Education. International Journal of Information and Communichttps://doi.org/10.4018/ijicte.2019010107

Lee, L. (2017). Learners' perceptions of the effectiveness of blogging for L2 writing in fully online language courses. International Journal of Computer-Assisted Language Learning and Teaching, 7(1), 19-33. https://doi.org/10.4018/IJCALLT.2017010102

Lenkaitis, C. A. (2019). Technology as a mediating tool: videoconferencing, L2 learning, and learner autonomy. Computer Assisted Language Learning, 0(0), 1-27. https://doi.org/10.1080/09588221.2019.1572018

Li, V. (2017). Social Media in English Language Teaching and Learning. International Journal of Learning and Teaching. https://doi.org/10.18178/ijlt.3.2.148-153

Mahmudi, A., Febriani, S. R., Hasanah, M., \& Arifa, Z. (2019). Classroom Management and Arabic Learning Process based on Multiple Intelligences in Elementary School. Arabiyat: Jurnal Pendidikan Bahasa Arab Dan Kebahasaaraban, 6(2), 222-237. https://doi.org/http://dx.doi.org/10.15408/a.v6i2.11365

Mellati, M., \& Khademi, M. (2015). The impacts of distance interactivity on learners' achievements in Online Mobile Language Learning: Social software and participatory learning. International Journal of Web-Based Learning and Teaching Technologies, 10(3), 19-35. https://doi.org/10.4018/ijwltt.2015070102

Mietzner, M., Muhtadi, B., Tinggi, S., Dakwah, I., Ciamis, S., Alam, M., Kosasih, E., Rohman, D. A., Anshori, I., Yanti, B. Z., Witro, D., Abubakar, I., Hemay, I., FAISAL, M., Hefni, W., Muhaimin, W., Syahputra, M. C., Sirozi, M., Arifinsyah, A., ... Anggraeni, A. D. (2020). Using Bloom's Taxonomy in Social Media Applications. Umbara, 1(1), 1-5. https://doi.org/10.1017/trn.2020.1

Moeller, A. J., \& Abbott, M. G. (2018). Creating a new normal: Language education for all. Foreign Language Annals, 51(1), 12-23. https://doi.org/10.1111/flan.12310

Moeller, A. J., \& Catalano, T. (2015). Foreign Language Teaching and Learning. International Encyclopedia of the Social \& Behavioral Sciences: Second Edition, 327-332. https://doi.org/10.1016/B978-0-08-097086-8.92082-8

Mohd, K. N., Mohd Adnan, A. H., Yusof, A. A., Ahmad, M. K., \& Mohd Kamal, M. A. (2019). Teaching Arabic Language to Malaysian University Students using Education Technologies based on Education 4.0 Principles. International Invention, Innovative \& Creative (InIIC) Conference, 2019, November, 38-51.

Nazmieva, E. I., Andreeva, E. A., \& Sakhibullina, K. A. (2019). Adaptation Potential of Foreign Language Teaching Educational Technologies in Russia. 10, 143-147.

Olmanson, J., \& Liu, X. (2018). The Challenge of Chinese Character Acquisition: Leveraging Multimodality in Overcoming a Centuries-Old Problem. The Emerging Learning Design Journal, 4(1), 1.

Pangondian, R.A., Santosa, P.I.,\&Nugroho, E. (2019). Faktor-Faktor Yang Mempengaruhi Kesuksesan Pembelajaran Daring Dalam Revolusi Industri 4.0. Seminar Nasional Teknologi Komputer \&Sains (SAINTEKS), 56-60.

Pininta. (2020, March). Bila Belajar di rumah diperpanjang: Tak harus Online dan Akademis. Kompas, 1.

Rabiman, R., Nurtanto, M., \& Kholifah, N. (2020). Design and development E-learning system by learning management system (Lms) in vocational education. International Journal of Scientific and Technology Research, 9(1), 1059-1063. 
Rear, D. (2017). The language deficit: a comparison of the critical thinking skills of Asian students in first and second language contexts. Asian-Pacific Journal of Second and Foreign Language Education, 2(1). https://doi.org/10.1186/s40862-017-0038-7

Richardson, J. C., Besser, E., Koehler, A., Lim, J., \& Strait, M. (2016). International Review of Research in Open and Distributed Learning Instructors ' Perceptions of Instructor Presence in Online Learning Environments. International Review of Research in Open and Distributed Learning, 17(4), 1-14.

Ritonga, A. W., Ritonga, M., Nurdianto, T., Kustati, M., Rehani, Lahmi, A., Yasmadi, \& Pahri. (2020). E-learning process of maharah qira'ah in higher education during the COVID-19 pandemic. International Journal of Higher Education, 9(6), 227-235. https://doi.org/10.5430/ijhe.v9n6p227

Safutri, J. T., Febriani, S. R., \& Hilmi, D. (2020). Improvement Of Arabic Language Tearcher Competency Based On Multiple Intelligences. Lughawiyyah, 2(1).

Setiawan, A. P. (2017). Aplikasi Teori Behavioristik dan Konstruktifistik dalam Kegiatan Pembelajaran di Sekolah Tinggi Ilmu Tarbiyah Raden Wijaya Mojokerto. Ta'dibia: Jurnal Ilmiah Pendidikan Agama Islam, 6(2), 33. https://doi.org/10.32616/tdb.v6i2.16

Shattock, M. (2017). The 'world class' university and international ranking systems: what are the policy implications for governments and institutions? Policy Reviews in Higher Education, 1(1), 4-21. https://doi.org/10.1080/23322969.2016.1236669

Shomurodovich, N. M. (2020). Using video material in teaching a foreign language in institutions. International Journal on Integrated Education, 3(V), 20-22.

Sicat, A. S. (2020). Enhancing College Students' Proficiency in Business Writing Via Schoology. Jurnal Ilmiah Pendidikan Biologi, 6(2), 214 -224.

So, S. (2016). Mobile instant messaging support for teaching and learning in higher education. Internet and Higher Education, 31, 32-42. https://doi.org/10.1016/j.iheduc.2016.06.001

Soffer, T., Kahan, T., \& Livne, E. (2017). E-assessment of online academic courses via students' activities and perceptions. Studies in Educational Evaluation, 54, 83-93. https://doi.org/10.1016/j.stueduc.2016.10.001

Soffer, T., \& Nachmias, R. (2018). Effectiveness of learning in online academic courses compared with face-to-face courses in higher education. Journal of Computer Assisted Learning, 34(5), 534-543. https://doi.org/10.1111/jcal.12258

Suparsa, I. N., Mantra, I. B. N., \& Widiastuti, I. A. M. S. (2017). Developing learning methods of Indonesian as a foreign language. International Journal of Social Sciences and Humanities, 1(2), 51-57. https://doi.org/10.29332/ijssh.v1n2.41

Turan, Z., \& Akdag-Cimen, B. (2020). Flipped classroom in English language teaching: a systematic review. Computer Assisted Language Learning, 33(5-6), 590-606. https://doi.org/10.1080/09588221.2019.1584117

Walder, A. M. (2017). Pedagogical Innovation in Canadian higher education: Professors' perspectives on its effects on teaching and learning. Studies in Educational Evaluation, 54, 71-82. https://doi.org/10.1016/j.stueduc.2016.11.001

Wargadinata, W., Maimunah, I., Febriani, S. R., \& Humaira, L. (2020). Mediated Arabic Language Learning for Arabic Students of Higher Education in COVID-19 Situation. Izdihar: Journal of Arabic Language Teaching, Linguistics, and Literature, 3(1), 59-78. https://doi.org/10.22219/jiz.v3i1.11862 
Wekke, I. S., \& Hamid, S. (2013). Technology on Language Teaching and Learning: A Research on Indonesian Pesantren. Procedia - Social and Behavioral Sciences, 83, 585-589. https://doi.org/10.1016/j.sbspro.2013.06.111

Yin, R. K. (2003). Robert K. Yin Case Study Research Design and Methods, Third Edition, Applied Social Research Methods Series, Vol 5 2002.pdf (pp. 1-181).

Zaharah, Z., \& Kirilova, G. I. (2020). Impact of Corona Virus Outbreak Towards Teaching and Learning Activities in Indonesia. SALAM: Jurnal Sosial Dan Budaya Syar-I, 7(3). https://doi.org/10.15408/sjsbs.v7i3.15104. 